\title{
Modeling the relationship between the characteristics of agricultural holdings and the presence of organic farming
}

\author{
Svetlana Roljević Nikolić1 ${ }^{*}$, Desimir Knežević2 ${ }^{\text {, Vesna Paraušić1 }}$ \\ ${ }^{1}$ Institute of Agricultural Economics, Volgina ulica 15, 11060 Belgrade, Serbia \\ 2 University of Priština, Faculty of Agriculture, Kopaonička bb, 38228, Lešak, Kosovo and Metohija, Serbia \\ *Corresponding author: svetlana_r@iep.bg.ac.rs
}

Received 29 April 2021; Accepted 27 September 2021

\begin{abstract}
A B S T R A C T
Organic farming is a fast growing market segment in the global food industry. Ecological and health benefits of organic farming are frequently emphasized. In addition, we have recently witnessed the promotion of its role in the development of rural areas by means of creating jobs and strengthening ties with local economies. This paper analyzes the relationship between the presence of organic farming and the main characteristics of agricultural holdings in the case of European Union countries. The objective is to identify factors which have a significant relationship with the organic farming sector and which can affect its future development. The results have shown that large farms are dominant in farm land management in the EU, which is related to the fact that there is a significant correlation between the availability of agricultural areas and the economic value of farms $\left(\mathrm{r}=0.881^{* *}\right)$. There is a positive and significant correlation between the economic value of a holding and the number of livestock units on the farm ( $\mathrm{r}=$ $0.940^{* *}$ ), which indicates that animal husbandry has strong economic potential. When it comes to the relationships between the structural and economic indicators of agricultural holdings and the presence of organic farming, the results have shown that the number of organic producers is positively and significantly correlated with the available agricultural areas $\left(\mathrm{r}=0.675^{* *}\right.$ ), and a strongly positively correlated with the economic value of farms $\left(r=0.810^{* *}\right)$. The areas under organic farming are also directly correlated with the utilized agricultural area $\left(r=0.836^{* *}\right)$, as well as with the number of livestock units $\left(r=0.793^{* *}\right)$, but they are slightly negatively correlated with livestock density $(r=-0.211)$. Therefore, high livestock density can be a limiting factor for the further intensive growth of organic farming areas, considering the significant impact of animal husbandry on the environment.
\end{abstract}

Keywords: holdings, agricultural land, livestock, economic value, organic production, environment.

\section{И 3 В О д}

Органска производња представља брзо растући сегмент тржишта у глобалној прехрамбеној индустрији. Често се истичу њене еколошке и здравствене предности, а у новије време промовише се и улога у развоју руралних подручја кроз стварање нових радних места и јачање веза са локалном економијом. У овом раду је анализиран однос између заступљености органске производње и главних карактеристика пољопривредних газдинстава на примеру земаља Европској унији. Циљ је да се идентификују чиниоци који су у значајној вези са сектором органске пољопривреде и могу да утичу на правце њеног даљег развоја. Резултати су показали да у управљању пољопривредним земљиштем у ЕУ доминирају велике фарме, што је у вези са чињеницом да је расположивост пољопривредним површинама у значајној корелацији са економском вредности фарми ( $\left.\mathrm{r}=0,881^{* *}\right)$. Утврђена је позитивна и значајна корелација између економске вредности газдинства и броја условних грла на фарми ( $\left.\mathrm{r}=0,940^{* *}\right)$, што указује на снажне економске потенцијале сектора сточарства. Када су у питању везе између структурних и економских показатеља пољопривредних газдинстава и заступљености органске производње, резултати су показали да је број органских произвођача у значајној и позитивној корелацији са расположивим пољопривредним површинама $\left(\mathrm{r}=0,675^{* *}\right)$, али и да је у снажној позитивној корелацији са економском вредности фарми $\left(\mathrm{r}=0,810^{* *}\right)$. Површине под органском производњом такође су у директној вези са коришћеним пољопривредним површинама $\left(\mathrm{r}=0,836^{* *}\right)$, као и са бројем условних грла $\left(\mathrm{r}=0,793^{* *}\right)$, али су у благој негативној корелацији са густином сточног фонда $(\mathrm{r}=-0,211)$. У том смислу, велика густина сточног фонда може представљати ограничавајући чинилац за даљи интензиван раст површина под органском производњом, с обзиром на значајан утицај који сектор сточарства има на животну средину.

Кључне речи: газдинства, пољопривредно земљиште, сточарство, економска вредност, органска производња, животна средина.

\section{Introduction}

Agriculture is a large and complex industry which involves rural areas and their communities, natural resources and human capital (Gradinaru and Mocuta, 2017). Its primary role is to ensure food security for people, but it is also a strong economic, social and ecological component of the development of numerous countries. In the European Union, this sector accounts for $1.6 \%$ of GDP, generates $4.5 \%$ of employment, and makes up $1.2 \%$ and $1.4 \%$ of all exports and imports, respectively (World Bank, 2019). Approximately 25\% 
of the total EU population live in rural areas. Therefore, there is a positive multiplier effect of agriculture in terms of preserving villages and rural regions and promoting the development of other direct and indirect activities such as agritourism, agribusiness and related industries (Dos Santos and Ahmad, 2020; Olorunfemi et al., 2020). In terms of ecology, the impact of organic farming on the environment and biodiversity should not be neglected.

The central political platform for the development of agriculture in the European Union is the Common Agricultural Policy (CAP), introduced in 1962. First, the focus of the agricultural policy was on the instruments prompting agricultural growth in order to ensure an independent and secure food supply. However, the 21st century has changed the role of agriculture in the economy. Nowadays, it is being transformed while paying special attention to sustainability. This is particularly evident in the subsidy system oriented towards solving ecologically important issues, such as land and water protection, improvement of biodiversity, preservation of genetic resources, and mitigation of greenhouse gas emissions (Kertész and Madarász, 2014). In such conditions, organic farming, as an ecologically, economically and socially sustainable system, has an important role and represents a significant element of the Common Agricultural Policy. It supports the key objectives of the European Union, such as improving food safety, promoting food quality, protecting the environment and decreasing the market surpluses of agricultural products.

Organic farming is a comprehensive system of farm management and food production which contributes to the preservation of natural resources and improvement of the social and economic aspects of the community (Bošković et al., 2016; Golijan et al., 2017). Organic farming regulations do not allow using pesticides and fertilizers, antibiotics, genetic engineering, irradiation and sewage sludge, and require using organic feed without hormones for animal production (Morgan and Murdoch, 2000). In this way, organic farming meets specific consumer demands regarding food safety, environmental protection and animal welfare, which has enabled this sector to grow fast in the recent period, particularly in developed countries. Research on consumer reactions to the availability of organic supermarkets in Germany has shown that consumers believe that organic food is environmentally friendly (3.93 on the 1-5 scale), that it enables farm animal welfare (3.82), is healthier (3.77), tastes better (3.43), does not contain pesticides (2.97) and that its consumption leads to personal satisfaction (2.18) (Gottschalk and Leistner, 2013). In comparison with conventional farming, oat grown in organic farming had a higher content of dietary fiber (DF) fractions, total dietary fiber (TDF) and insoluble dietary fiber (IDF), while barley had a higher content of soluble dietary fiber (SDF) fractions (Menkovska et al., 2017). Also, organically grown wheat had high levels of minerals ( $\mathrm{Cu}, \mathrm{Zn}, \mathrm{Fe}, \mathrm{Mn}$ ), while the values of $\mathrm{Cr}$ and $\mathrm{Cd}$ were below the EU limits (Laze et al., 2018). This is important for the nutritional value and preservation of healthy soil.

An important factor contributing to the growth of the organic sector is financial performance. Namely, in addition to the higher prices of organic products realized on the market, the strong growth of this sector is also encouraged by the financial support provided to organic producers by a large number of countries (Brožová, 2011; Roljević Nikolić et al., 2017). The results of a three-year examination of organic and conventional farms showed that organic farms mainly had greater profitability than conventional farms, but that this result was conditioned by subsidies (Brožová and Vaněk, 2013).

However, regardless of the subsidy system, reaching economic efficiency in the organic farming sector is still more complex than in other sectors, primarily due to the specific production process, stricter regulations in the production process, labeling and sale of organic products, which all increases the costs and can affect the economic efficiency of this production. Studies indicate that, in comparison to conventional farming, the efficiency and profitability of organic farming depend on the production orientation of a holding, applied technology and subsidy system (Brožová and Vaněk, 2013; Madau, 2005), as well as on many other factors in the micro- and macro-economic environment of farms (Offermann and Nieberg, 2000).

The objective of this paper is to determine the relationship between structural and economic characteristics of agricultural holdings, on the one hand, and the presence of organic farming, on the other, as well as to identify the factors that can significantly affect the further development of the organic farming sector.

\section{Materials and methods}

The study of the relationship between the structural and economic characteristics of agricultural holdings and the presence of organic farming was conducted at the European Union country level, in order to ensure data consistency. The analysis of the structural and economic factors of agricultural holdings in the EU countries used the data of the statistical office of the European Union (Eurostat) obtained in the survey of agricultural holdings (Farm structure survey) in 2016. The analysis involved the following indicators: (1) total number of agricultural holdings, (2) utilized agricultural area (UAA) (ha), (3) UAA by farm size classes (ha), (4) UAA by economic size classes ( $€$ ), (5) farms with livestock - number, (6) number of livestock units (LSU) at holdings and (7) standard output SO (€). On the basis of the available data, two additional structural factors were created: number of livestock units per utilized agricultural area unit (LSU / UAA), average number of livestock units per farm (LSU / Farm), as well as one economic indicator: the average economic value of the farm (SO / Farm).

The analysis of the presence of organic farming in the EU used the 2018 data of the Research Institute of Organic Agriculture (FiBL). The following indicators were analyzed: (1) area under organic farming (ha) and (2) number of organic producers, on the basis of which (3) the average area of organic farms in all EU member countries was calculated.

The data analysis was divided into two fundamental steps: a) methods of descriptive statistics were used to conduct the analysis of structural and economic characteristics of agricultural holdings, as well as the parameters in the organic farming sector, presented by means of tables and graphs, and b) correlation analysis was used to determine the strength and direction of the correlation between the selected 
indicators. The statistical significance of Pearson's correlation coefficient was tested at the 0.05 level. All analyses were conducted in IBM SPSS Statistics 25.

\section{Results and discussions}

\subsection{Main characteristics of farms in the European Union}

The structure of agriculture in the EU member countries varies depending on geology, climate, natural resources, and specificities of regional production, infrastructure and tradition (Gradinaru and Mocuta, 2017). According to the Eurostat data, the EU countries have 173336240 ha of UAA. The largest parts of these areas are in France $(17.8 \%)$ and Spain (14.8\%), which manage one third of the EU community's UAA. On the other hand, there are 10467860 farms in the EU, which have 16.6 ha of UAA on average (Table 1). The largest number of farms is registered in Romania, as many as 3 422 030, which accounts for the third of the total number of EU farms. Owing to the large number of holdings, Romania, in addition to Cyprus (3.2 ha) and Malta (1.2 ha), has the smallest average farm size (3.7 ha), which is four times smaller than the EU average. The largest average farm size is at the holdings in Czechia (130.2 ha).

Table 1.

The main structural and economic indicators of agricultural holdings in the European Union

\begin{tabular}{|c|c|c|c|c|c|c|c|}
\hline Country & UAA - ha & $\begin{array}{l}\text { Farm - } \\
\text { number }\end{array}$ & $\begin{array}{l}\text { Farms with } \\
\text { livestock - } \\
\text { number }\end{array}$ & $\begin{array}{l}\text { Livestock } \\
\text { unit (LSU) on } \\
\text { farms }\end{array}$ & $\begin{array}{l}\text { LSU / } \\
\text { UAA }\end{array}$ & $\begin{array}{l}\text { LSU / } \\
\text { Farm }\end{array}$ & $\begin{array}{l}\text { SO }(€) / \\
\text { Farm }\end{array}$ \\
\hline Belgium & 1354250 & 36890 & 25440 & 3772750 & 2.8 & 148.3 & 217891 \\
\hline Bulgaria & 4468500 & 202720 & 134970 & 1094240 & 0.2 & 8.1 & 18957 \\
\hline Czechia & 3453040 & 26530 & 18680 & 1756520 & 0.5 & 94.0 & 191555 \\
\hline Denmark & 2614600 & 35050 & 20670 & 4128470 & 1.6 & 199.7 & 287088 \\
\hline Germany & 16715320 & 276120 & 184690 & 18182310 & 1.1 & 98.4 & 178361 \\
\hline Estonia & 995100 & 16700 & 6960 & 279330 & 0.3 & 40.1 & 47997 \\
\hline Ireland & 4883650 & 137560 & 126590 & 6199890 & 1.3 & 49.0 & 45,979 \\
\hline Greece & 4553830 & 684950 & 238520 & 2102870 & 0.5 & 8.8 & 11,059 \\
\hline Spain & 23229750 & 945020 & 216700 & 14442530 & 0.6 & 66.6 & 40598 \\
\hline France & 27814160 & 456520 & 247570 & 22081990 & 0.8 & 89.2 & 134371 \\
\hline Croatia & 1562980 & 134460 & 91470 & 754710 & 0.5 & 8.3 & 15134 \\
\hline Italy & 12598160 & 1145710 & 154680 & 9467720 & 0.8 & 61.2 & 45115 \\
\hline Cyprus & 111930 & 34940 & 9980 & 172080 & 1.5 & 17.2 & 17650 \\
\hline Latvia & 1930880 & 69930 & 44970 & 498640 & 0.3 & 11.1 & 17465 \\
\hline Lithuania & 2924600 & 150320 & 95300 & 849990 & 0.3 & 8.9 & 14810 \\
\hline Luxembourg & 130650 & 1970 & 1540 & 173600 & 1.3 & 112.7 & 185283 \\
\hline Hungary & $4,670,560$ & 430000 & 261540 & 2444890 & 0.5 & 9.3 & 15192 \\
\hline Malta & 11180 & 9310 & 2740 & 32470 & 2.9 & 11.9 & 10642 \\
\hline Netherlands & 1796260 & 55680 & 36960 & 6819960 & 3.8 & 184.5 & 414638 \\
\hline Austria & 2669750 & 132500 & 93920 & 2432030 & 0.9 & 25.9 & 46351 \\
\hline Poland & 14405650 & 1410700 & 718240 & 9443240 & 0.7 & 13.1 & 17726 \\
\hline Portugal & 3641690 & 258980 & 172350 & 2223720 & 0.6 & 12.9 & 19863 \\
\hline Romania & 12502540 & 3422030 & 2567430 & 4828780 & 0.4 & 1.9 & 3538 \\
\hline Slovenia & 488400 & 69900 & 56580 & 512120 & 1.0 & 9.1 & 16578 \\
\hline Slovakia & 1889820 & 25660 & 16120 & 621590 & 0.3 & 38.6 & 75270 \\
\hline Finland & 2233080 & 49710 & 16610 & 1102310 & 0.5 & 66.4 & 70702 \\
\hline Sweden & 3012640 & 62940 & 34290 & 1699990 & 0.6 & 49.6 & 81962 \\
\hline United Kingdom & 16673270 & 185060 & 138050 & 13340200 & 0.8 & 96.6 & 137271 \\
\hline EU 28 & 173336240 & 10467860 & 5733560 & 131458940 & 0.8 & 22.9 & 34784 \\
\hline
\end{tabular}

Source: Eurostat (2016) and authors' calculations

When it comes to farm size, expressed by means of the available UAA, the largest number of farms in the EU $(65.6 \%)$ belong to the category of "small holdings", which are less than 5 ha. These holdings manage only $6.1 \%$ of the community's UAA (Figure 1). The next most numerous holdings are those in size class $5-9.9$ ha, which manage about $5 \%$ of the total UAA. The data presented in Graph 1 indicate that the increase in farm size decreases the number of holdings, but increases their share in the total UAA. Thus, farms in size class of 100 or more hectares account for only $3.3 \%$ of the total number of holdings, but manage more than $50 \%$ of UAA in the EU (Figure 1). The obtained results highlight the aggregation of agricultural areas on a small number of large farms. This tendency has a negative effect on the development and economic strength of small holdings, which cannot compete with large producers in the market. The results of a study conducted in the EU Baltic countries have shown that small and medium-sized holdings are disappearing, while the number of large farms is increasing. The most drastic fall was recorded in Poland, where more than one million small farms and more than 300000 mediumsized farms disappeared in the period from 2005 to 2016 (Ambros and Granvik, 2020). The same authors concluded that this tendency could be a consequence of the common agricultural policy of the EU, which often supports large farms rather than small family holdings. 


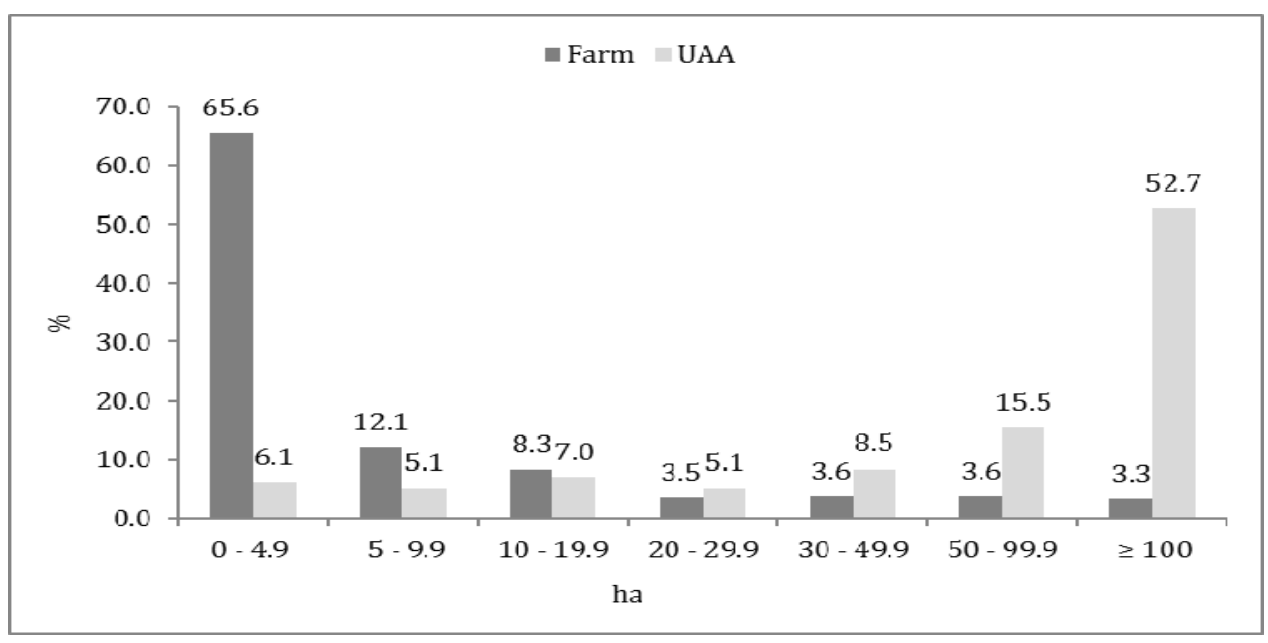

Figure 1. Distribution of the number of farms and utilized agricultural area by farm size class Source: Eurostat (2016) and author's calculation

The animal husbandry sector has large economic potential. In addition to food production, livestock on a farm enables production diversification and revenue growth (Moyo and Swanepoel, 2010). More than half of the EU holdings breed animals on farms (Table 1). The greatest number of farms with livestock is registered in Romania (2 567 430), but the largest share of livestock farms in the total number of farms is in Ireland, where as many as $92 \%$ of the total number of holdings breed animals on their farms. It is followed by Slovenia (80.9\%), Luxembourg (78.2\%), Romania (75.0), the United Kingdom (74.6\%), Austria (70.9\%) and Czechia (70.4\%). The share of holdings with livestock in the other member countries is smaller than $70 \%$. The average number of livestock units (LSU) per holding in the EU is 22.9 , ranging from 1.9 in Romania to 199.7 in Denmark.
Another significant structural indicator of agricultural holdings is livestock density, expressed as the number of LSU per unit of UAA. The average livestock density in the EU has reached 0.8 livestock units per hectare of UAA, ranging from 0.2 in Bulgaria to 3.8 in the Netherlands. High livestock density is also registered in Malta (2.9), Belgium (2.8), Denmark (1.6), Cyprus (1.5), Ireland (1.3), Luxembourg (1.3) and Germany (1.1). In the other member countries, livestock density is lower than 1 (Table 1). In addition to being an important structural indicator, livestock density is a significant agro-ecological indicator measuring the impact of cattle breeding on the environment and varying depending on the intensity of agricultural production.

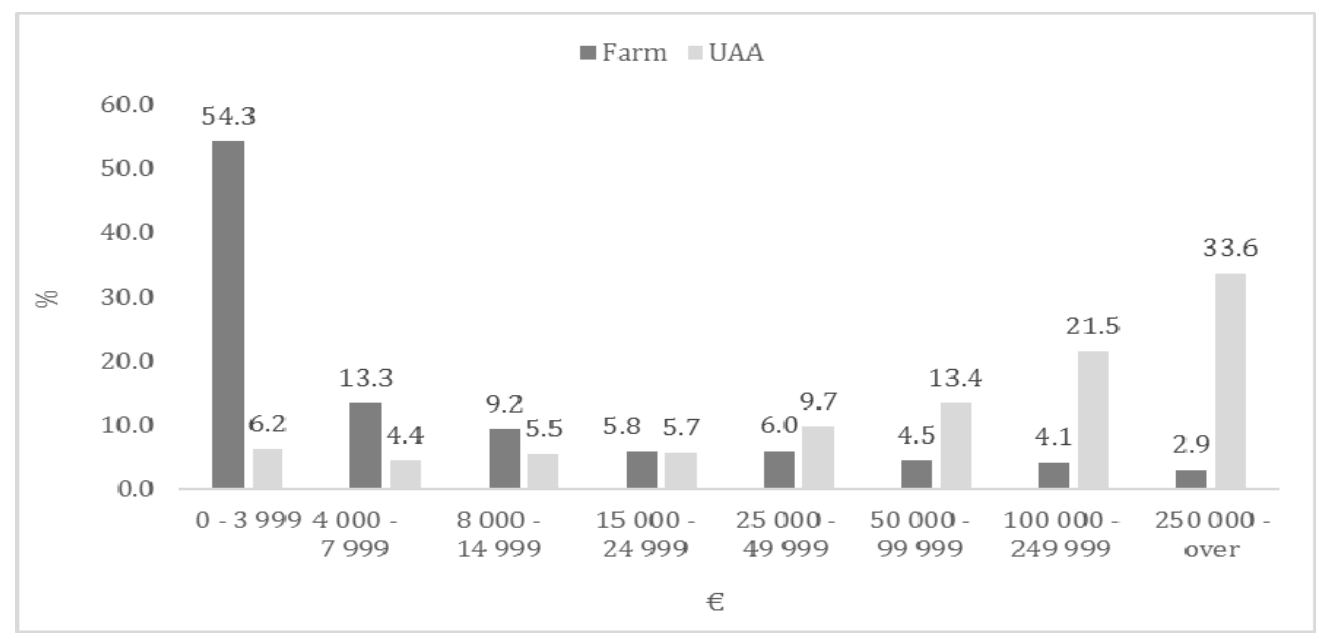

Figure 2. Distribution of the number of holdings and utilized agricultural area (UAA) by economic size class Source: Eurostat (2016) and author's calculation

In addition to the structural characteristics, holdings have significant economic value, expressed as Standard Output (abbr. SO) or the average monetary value of the agricultural output at farm-gate price, in euro (Paraušić and Cvijanović, 2014). The average economic value of holdings in the EU is €34 784, ranging from €3 538 in Romania to €414 638 in the Netherlands. With regard to the production value in relation to UAA size, the results show that the largest percentage of holdings (54.3\%) belong to the smallest economic class - up to €3 999 (Figure 2). The holdings belonging to the smallest economic class manage a very 
small share of the total UAA (6.2\%). On the other hand, the holdings in the economic size of $€ 100000$ or more, which structurally account for $7 \%$, manage $55 \%$ of the total UAA of the EU community (Figure 2). A number of other authors have also highlighted this skewed distribution of small and large holdings (Davidova et al., 2012; Tudor, 2015; Unay-Gailhard and Bojnec, 2015). The obtained results indicate that land availability can have a strong effect on the economic value of a holding. However, one should bear in mind that there are very intensive activities which create high production value using a small agricultural area, such as growing flowers, producing specially designated wines, breeding poultry, etc. Guiomar et al. (2018) highlighted that farms which were large in size frequently had low income and consequently a small economic size.

\subsection{Main characteristics of farms under organic production in the $E U$}

The development of organic agriculture in the EU countries is a consequence of the transformation of economic and social policies, particularly the agricultural policy. Namely, throughout the 20th century, the EU policy focused on instruments for encouraging production growth in order to ensure an independent and secure food supply. However, the 21st century changed the role of agriculture in economy and transformed it towards sustainability.

Today, organic farming is one of the fastest growing agricultural sectors in the world, particularly in the European Union (Jezierska-Thöle et al., 2017). In the EU, organic farming is practiced on 13.8 million ha, which accounts for $8.0 \%$ of the total UAA (Table 2). A third of the total area under organic farming is located in Spain (2 246475 ha) and France (2 035024 ha). Italy and Germany also have significant areas under organic farming - 1958045 ha and 1521314 ha, respectively. The share of organic areas in UAA differs among the EU member countries. The countries with the largest share of organic areas in UAA are Austria (23.9\%), Estonia (20.8\%) and Sweden (20.2\%). Spain and France have respectively $9.7 \%$ and $7.3 \%$ of organic areas in UAA, while the lowest number of organic areas is recorded in Malta (0.4\%), followed by Ireland (2.4), Romania (2.6\%) and the United Kingdom (2.7\%).

Table 2.

Indicators of the presence of organic farming in the European Union

\begin{tabular}{|c|c|c|c|c|c|c|c|}
\hline \multirow[b]{2}{*}{ Country } & \multirow{2}{*}{$\begin{array}{l}\text { Organic } \\
\text { area, ha }\end{array}$} & \multirow{2}{*}{$\begin{array}{l}\text { Organic } \\
\text { producers }\end{array}$} & \multirow{2}{*}{$\begin{array}{l}\text { Organic } \\
\text { area in UAA, } \\
\%\end{array}$} & \multirow{2}{*}{$\begin{array}{l}\text { Organic farm } \\
\text { in Farms total, } \\
\%\end{array}$} & \multicolumn{2}{|c|}{ Average UAA per farm, ha } & \multirow[b]{2}{*}{$\mathrm{OF}: \mathrm{CF}$} \\
\hline & & & & & All farms & $\begin{array}{l}\text { Organic } \\
\text { farms }\end{array}$ & \\
\hline Belgium & 89025 & 2264 & 6.6 & 6.1 & 36.7 & 39.3 & $\nearrow$ \\
\hline Bulgaria & 162332 & 6471 & 3.6 & 3.2 & 22.0 & 25.1 & $\nearrow$ \\
\hline Czechia & 538894 & 4601 & 15.6 & 17.3 & 130.2 & 117.1 & $\downarrow$ \\
\hline Denmark & 256711 & 3637 & 9.8 & 10.4 & 74.6 & 70.6 & $\downarrow$ \\
\hline Germany & 1521314 & 31713 & 9.1 & 11.5 & 60.5 & 48.0 & $\downarrow$ \\
\hline Estonia & 206590 & 1948 & 20.8 & 11.7 & 59.6 & 106.1 & $\nearrow$ \\
\hline Ireland & 118699 & 1725 & 2.4 & 1.3 & 35.5 & 68.8 & $\nearrow$ \\
\hline Greece & 492627 & 29594 & 10.8 & 4.3 & 6.6 & 16.6 & $\nearrow$ \\
\hline Spain & 2246475 & 39505 & 9.7 & 4.2 & 24.6 & 56.9 & $\nearrow$ \\
\hline France & 2035024 & 41632 & 7.3 & 9.1 & 60.9 & 48.9 & $\downarrow$ \\
\hline Croatia & 103166 & 4374 & 6.6 & 3.3 & 11.6 & 23.6 & $\nearrow$ \\
\hline Italy & 1958045 & 69317 & 15.5 & 6.1 & 11.0 & 28.2 & $\nearrow$ \\
\hline Cyprus & 6022 & 1249 & 5.4 & 3.6 & 3.2 & 4.8 & $\nearrow$ \\
\hline Latvia & 280383 & 4178 & 14.5 & 6.0 & 27.6 & 67.1 & $\nearrow$ \\
\hline Lithuania & 239691 & 2476 & 8.2 & 1.6 & 19.5 & 96.8 & $\nearrow$ \\
\hline Luxembourg & 5782 & 103 & 4.4 & 5.2 & 66.3 & 56.1 & $\downarrow$ \\
\hline Hungary & 209382 & 3,929 & 4.5 & 0.9 & 10.9 & 53.3 & $\nearrow$ \\
\hline Malta & 47 & 19 & 0.4 & 0.2 & 1.2 & 2.5 & $\nearrow$ \\
\hline Netherlands & 57904 & 1696 & 3.2 & 3.0 & 32.3 & 34.1 & $\nearrow$ \\
\hline Austria & 637805 & 25795 & 23.9 & 19.5 & 20.1 & 24.7 & $\nearrow$ \\
\hline Poland & 484676 & 19224 & 3.4 & 1.4 & 10.2 & 25.2 & $\nearrow$ \\
\hline Portugal & 213118 & 5213 & 5.9 & 2.0 & 14.1 & 40.9 & $\nearrow$ \\
\hline Romania & 326260 & 7908 & 2.6 & 0.2 & 3.7 & 41.3 & $\nearrow$ \\
\hline Slovenia & 47848 & 3738 & 9.8 & 5.3 & 7.0 & 12.8 & $\nearrow$ \\
\hline Slovakia & 188986 & 439 & 10.0 & 1.7 & 73.6 & 430.5 & $\nearrow$ \\
\hline Finland & 297442 & 5129 & 13.3 & 10.3 & 44.9 & 58.0 & $\nearrow$ \\
\hline Sweden & 608758 & 5801 & 20.2 & 9.2 & 47.9 & 104.9 & $\nearrow$ \\
\hline UK & 457377 & 3544 & 2.7 & 1.9 & 90.1 & 129.1 & $\nearrow$ \\
\hline EU 28 & 13790384 & 327222 & 8.0 & 3.1 & 16.6 & 42.1 & $\nearrow$ \\
\hline
\end{tabular}

Source: Eurostat, Fibl and author's calculation

In the EU, there are still a small number of holdings using the organic production system, which leads to a large average size of these farms. Namely, according to the Eurostat and FiBL data, only $3.1 \%$ of EU holdings apply organic farming methods. In most countries (22), the share of farms under organic farming is lower than
10\%, while Austria (19.5\%) and Czechia (17.3\%) have the largest percentage of farms in the organic farming sector.

Analyzing the organic farming sector in the EU countries, Offermann and Nieberg (2000) found that the average size of an organic farm was larger than the 
size of conventional farms in most countries. This can be confirmed by the official statistical data presented in Table 2. Namely, the average size of all farms in the European Union is $16.6 \mathrm{ha}$, while the average size of organic farms is 42.1 ha. Only five EU countries have the average size of all farms higher than organic farms - Czechia (130.2 vs. 117.1 ha), Denmark (74.6 vs. 70.6 ha), Germany (60.5 vs. 48.0 ha), France (60.9 vs. 48.9 ha) and Luxembourg (66.3 vs. $56.1 \mathrm{ha}$ ) (Table 2). On the other hand, organic farm area is significantly larger than the size of all farms in Slovakia (6 times larger), Lithuania (5 times larger), Hungary (5 times larger), and Portugal (3 times larger).

\subsection{The relationship between the main characteristics of all farms and the presence of organic farming}

Land, a key basis in an agricultural system, has a very important role in rural livelihoods and food security (Naseer et al., 2016). The correlation analysis of the structural and economic characteristics of EU holdings shows that the number of farms is directly correlated with utilized agricultural area $\left(\mathrm{r}=0.462^{*}\right)$. In addition, there is a strong correlation between UAA and number of LSU $\left(r=0.930^{* *}\right)$. The linear regression formula shows that the increase in UAA by 1 ha leads to a linear increase in LSU by 0.74 (ŷi $=120484.1+$ $0.739 * x i)$. This strong correlation between the crop and animal production is the prerequisite for developing agriculture as the key resource base and reaching food security.

Among the analyzed indicators, the economic value of the farm has the strongest correlation with utilized agricultural areas $\left(\mathrm{r}=0.881^{* *}\right)$ and the total number of livestock units $\left(r=0.940^{* *}\right)$. Terres et al. (2015) indicated that farms managing a greater area had lower production costs, used machines and production inputs more efficiently, applied innovations more frequently, and consequently were more economically competitive. However, numerous authors also stated that the opposite could frequently be the case (Davidova et al., 2012; Tocco et al., 2013). Still, the strongest correlation was obtained between the economic value of the holding and the number of livestock units $\left(r=0.940^{* *}\right)$, which indicates that the animal husbandry sector has strong economic effects. On the basis of the simple linear regression formula $(\hat{y} \mathrm{i}=107805567.7+$ $\left.2746.9^{*} \mathrm{xi}\right)$, it can be seen that a unit increase in LSU on farms leads to a rise in the total standard output (SO) by $€ 2,746.9$.

Table 3.

Results of Pearson's correlation coefficient analysis of the structural and economic indicators of all farms and indicators of the presence of organic farming

\begin{tabular}{llllllllll}
\hline Indicators & $\begin{array}{l}\text { Farm - } \\
\text { number }\end{array}$ & UAA & $\begin{array}{l}\text { Farm }- \\
\text { with } \\
\text { livestock }\end{array}$ & LSU & $\begin{array}{l}\text { LSU / } \\
\text { UAA }\end{array}$ & $\begin{array}{l}\text { LSU / } \\
\text { Farm }\end{array}$ & $\begin{array}{l}\text { SO } \\
\text { Farm }\end{array}$ & $\begin{array}{l}\text { Organic } \\
\text { producers }\end{array}$ & $\begin{array}{l}\text { Organic } \\
\text { area }\end{array}$ \\
\hline $\begin{array}{l}\text { Farm- } \\
\text { number }\end{array}$ & 1 & $0.462^{*}$ & $0.946^{* *}$ & 0.256 & -0.231 & -0.259 & 0.300 & 0.343 & 0.269 \\
UAA-ha & $0.462^{*}$ & 1 & 0.325 & $0.930^{* *}$ & -0.211 & 0.097 & $0.881^{* *}$ & $0.675^{* *}$ & $0.836^{* *}$ \\
Farm with & $0.946^{* *}$ & 0.325 & 1 & 0.142 & -0.196 & -0.255 & 0.120 & 0.079 & 0.048 \\
livestock & 0.256 & $0.930^{* *}$ & 0.142 & 1 & 0.045 & 0.339 & $0.940^{* *}$ & $0.635^{* *}$ & $0.793^{* *}$ \\
LSU & -0.231 & -0.211 & -0.196 & 0.045 & 1 & $0.578^{* *}$ & 0.037 & -0.177 & -0.211 \\
LSU / UAA & -0.259 & 0.097 & -0.255 & 0.339 & $0.578^{* *}$ & 1 & 0.317 & 0.007 & 0.131 \\
LSU / Farm & 0.300 & $0.881^{* *}$ & -0.230 & 0.940 & 0.037 & 0.317 & 1 & $0.810^{* *}$ & $0.879^{* *}$ \\
$\begin{array}{l}\text { SO Farm } \\
\text { Organic }\end{array}$ & 0.343 & $0.675^{* *}$ & 0.079 & $0.635^{* *}$ & -0.177 & 0.007 & $0.810^{* *}$ & 1 & $0.892^{* *}$ \\
producers & 0.269 & $0.836^{* *}$ & 0.048 & $0.793^{* *}$ & -0.211 & 0.131 & $0.879^{* *}$ & $0.892^{* *}$ & 1 \\
\hline Organic area & 0.269 & & & & &
\end{tabular}

*. Correlation is significant at the 0.05 level (2-tailed).

**. Correlation is significant at the 0.01 level (2-tailed).

The analysis of the structural and economic characteristics of agricultural holdings in the EU countries and the indicators of the presence of organic farming determined a strong correlation between the number of organic producers and total UAA ( $\mathrm{r}=$ $0.675^{* *}$ ). On the other hand, the correlation with the total number of farms was weaker $(r=0.343)$. Unlike the correlation with the total number of all farms $(\mathrm{r}=$ 0.300 ), a high correlation coefficient was obtained between the number of organic producers and the economic value of farms $\left(\mathrm{r}=0.810^{* *}\right)$. Tzouvelekas et al. (2001a, 2001b) found that differences in the economic efficiency of conventional and organic farms depend not only on the farm's production orientation but also on the production region and the applied technology. Brožová and Vaněk (2013) emphasized that subsidy system has the key role in reaching the profitability of organic farms.
The analysis results show that the areas under organic farming are directly correlated with the total UAA $\left(r=0.836^{* *}\right)$ and the number of organic producers $\left(\mathrm{r}=0.892^{* *}\right)$. There is a strong and significant relationship between the areas under organic farming and the economic value of farms $\left(r=0.879^{* *}\right)$. In addition, there is a strong correlation with the number of livestock units $\left(\mathrm{r}=0.793^{* *}\right)$, which is related to the significance of organic fertilizers in maintaining soil fertility in this production system. On the other hand, there is a negative correlation between the areas under organic farming and livestock density $(r=-0.211)$. This is expected since this indicator shows the impact of animal husbandry on the environment. In the case of intensive cattle breeding, there is a strong pressure of nitrate on soil and air, which creates unfavorable conditions for organic farming. 


\section{Conclusions}

Conventional agriculture provides the key support for the agro-industrial sector, but organic farming is becoming an increasingly important part of it. Therefore, in recent years, the agricultural policy of a large number of countries worldwide has been more focused on high-quality safe food production than on the market mechanisms of this sector. Generally, organic producers manage a greater average UAA than other holdings. It has been determined that the areas under organic farming are directly correlated with the available agricultural area $\left(\mathrm{r}=0.836^{* *}\right)$ as well as with the number of livestock units $\left(r=0.793^{* *}\right)$, which is related to the role of animal husbandry in maintaining soil fertility in organic farming. On the other hand, livestock density is negatively correlated with both indicators of the presence of organic farming $(r=$ 0.177 and $r=-0.211$ ). The obtained results show that livestock density, more than the other analyzed indicators, can be a limiting factor for the further development of the organic food production sector, considering the strong pressure that intensive animal husbandry places on the environment.

\section{Acknowledgment}

This paper is the result of research under the "Contract on the scientific research work realization and financing in 2021 between the Institute of Agricultural Economics in Belgrade and the Ministry of Education, Science and Technological Development of the Republic of Serbia”, Ref. No: 451-03-9/2021-14.

\section{Declaration of competing interest}

The authors declare no conflicts of interest.

\section{References}

Ambros, P., Granvik, M. (2020). Trends in Agricultural Land in EU Countries of the Baltic Sea Region from the Perspective of Resilience and Food Security. Sustainability, 12(14), 5851.

Bošković, J., Hojka, Z., Zečević, V., Prodanović, R., Vukić, M. (2016). Significant resources of sustainable agriculture and organic food production system in Serbia. Acta Agriculturae Serbica, 21(41), 65-83.

Brožová, I., Vanek, J. (2013). Assessment of economic efficiency of conventional and organic agricultural enterprises in a chosen region. Acta Universitatis Agriculturae et Silviculturae Mendelianae Brunensis, 2, 297-307.

Brožová, I. (2011). The economic performance analysis of organic farms in the Czech Republic. Agricultural Economics Czech, 57(5), 240-246.

Davidova, S., Fredriksson, L., Gorton, M., Mishev, P., Petrovici, D. (2012). Subsistence farming, incomes, and agricultural livelihoods in the new member states of the European Union. Environment and Planning C: Government and Policy, 30, 209-227.

Dos Santos, M.J.P. L., Ahmad, N. (2020). Sustainability of European agricultural holdings. Journal of the Saudi Society of Agricultural Sciences, 19(5), 358-364.

Eurostat https://ec.europa.eu/eurostat/data/database date of access 23/01/2021

FiBL Statistics https://statistics.fibl.org/europe/keyindicators.html date of access 25/01/2021

Golijan, J., Veličković, M., Dimitrijević, B., Marković, D. (2017). Plant production by the concept of organic agriculture in the world and Serbia: History and current status. Acta Agriculturae Serbica, 22(43), 67-88.

Gottschalk, I., Leistner, T. (2013). Consumer reactions to the availability of organic food in discount supermarkets. International Journal of Consumer Studies, 37, 136-142.

Gradinaru, I., Mocuta, D. (2017). Farm structures in the European Union. Scientific Papers Series Management, Economic Engineering in Agriculture and Rural Development, 17(1), 223-230.

Guiomar, N., Godinho, S., Pinto-Correia, T., Almeida, M., Bartolini, F., Bezak, P., ..., Wästfelt, A. (2018). Typology and distribution of small farms in Europe: Towards a better picture. Land Use Policy, 75, 784-798.

Jezierska-Thöle, A., Gwiaździńska-Goraj, M. Wiśniewski, Ł. (2017). Current status and prospects for organic agriculture in Poland. Quaestiones Geographicae, 36(2), 23-36.

Kertész, Á., Madarász, B. (2014). Conservation Agriculture in Europe. International Soil and Water Conservation Research, 2(1), 91-96

Laze, A., Arapi, V., Brahushi, F., Pezo, L., Kristl, J., Riciputi, Y., Knezevic, D. (2018). Assessment of Microelements Content in Organic Soft Albanian Wheat Genotypes. International Journal of Innovative Approaches in Agricultural Research, 2(4), 295-306.

Madau, F. (2005). Technical efficiency in organic farming: an application on Italian cereal farms using a parametric approach. In Conference Proceedings from XIth Congress of the EAAE (European Association of Agricultural Economists) 'THE FUTURE OF RURAL EUROPE IN THE GLOBAL AGRI-FOOD SYSTEM', Copenhagen, Denmark, August 24-27, 2005, 1-15.

Menkovska, M., Levkov, V., Damjanovski, D., Gjorgovska, N., Knežević, D., Nikolova, N., Andreevska, D. (2017). Content of TDF, SDF and IDF in Cereals Grown by Organic and Conventional Farming - a Short Report. Polish Journal of Food and Nutrition Sciences, 67(3), 241-244.

Morgan, K., Murdoch, J. (2000). Organic vs. conventional agriculture: knowledge, power and innovation in the food chain. Geoforum, 31, 159-173.

Moyo, S., Swanepoel, F.J.C. (2010). Multifuncionality of livestock in developing communities. In: The Role of Livestock in Developing Communities: Enhancing Multifunctionality, edited by Frans Swanepoel, Aldo Stroebel and Siboniso Moyo, 3, 69.

Naseer, A., Ashfaq, M., Abid, M., Razzaq, A., Hassan, S. (2016). Current status and key trends in agricultural land holding and distribution in Punjab, Pakistan: Implications for food security. Journal of Agricultural Studies, 4(4), 14-27.

Offermann, F., Nieberg, H. (2000). Profitability of organic farming in Europe. In: IFOAM 2000 - The World Grows Organic. Proceedings 13th International IFOAM Scientific Conference, Basel 28-31 August 2000, pp. 666-669

Olorunfemi, T.O., Olorunfemi, O.D., Oladele, O.I. (2020). Determinants of the involvement of extension agents in disseminating climate smart agricultural initiatives: Implication for scaling up. Journal of the Saudi Society of Agricultural Sciences, 19(4), 285-292.

Paraušić, V., Cvijanović, D. (2014). Ekonomska veličina poljoprivrednih gazdinstava u Srbiji i preporuka mera za njihovo osnaživanje. In Zbornik radova - Završna konferencija Primena podataka popisa poljoprivrede, 2830.

Roljević Nikolić, S., Vuković P., Grujić, B. (2017). Measures to support the development of organic farming in the EU and Serbia. Economics of Agriculture, LXIV(1), 323-337.

Terres, J.M., Scacchiafichi, L.N., Wania, A., Ambar, M., Anguiano, E., Buckwell, A., ... Zobena, A. (2015). Farmland abandonment in Europe: Identification of drivers and indicators, and development of a composite indicator of risk. Land Use Policy, 49, 20-34.

Tocco, B., Davidova S., Bailey A. (2013). Determinants to leave agriculture in the EU J. Swinnen, L. Knops (Eds.), Land, Labour and Capital Markets in European Agriculture: Diversity Under a Common Policy, Centre for European Policy Studies, Brussels, 154-170 
Tudor, M.M. (2015). Small scale agriculture as a resilient system in rural Romania. Studies in Agricultural Economics, 117, 27-34.

Tzouvelekas, V., Pantzios, C.J., Fotopoulos, C. (2001a). Economic efficiency in organic farming: evidence from cotton farms in Viotia. Greece. Journal of Agricultural and Applied Economics, 33, 35-48.

Tzouvelekas, V., Pantzios, C.,J., Fotopoulos C. (2001b). Technical efficiency of alternative farming systems: the case of Greek organic and conventional olive-growing farms. Food Policy, 26, 549-569.

Unay-Gailhard, I., Bojnec, Š. (2015). Farm size and participation in agri-environmental measures: Farm-level evidence from Slovenia, Land Use Policy, 46, 273-282. http://dx.doi.org/10.1016/j.landusepol.2015.03.002

World

Bank https://data.worldbank.org/indicator/NV.AGR.TOTL.ZS?I ocations=EU date of access 05/04/2021 